Cell Research (1998), 8, 99-103

\title{
On the history of nuclear matrix manifestation
}

\author{
ZBARSKY IB \\ N.K. Koltzov Institute of Developmental Biology, Russian \\ Academy of Sciences. 26, Vavilov Street, 117334 Moscow, \\ Russia.e-mail:ibzba@ibrran.msk.su
}

\begin{abstract}
The nonchromatin proteinous residue of the cell nucleus was revealed in our laboratory as early as in 1948 and then identified by light and electron microscopy as residual nucleoli, intranuclear network and nuclear envelope before 1960. This structure termed afterwards as "nuclear residue", "nuclear skeleton", "nuclear cage", "nuclear carcass" etc., was much later (in 1974) isolated, studied and entitled as "nuclear matrix" by Berezney and Coffey, to whom the discovery of this residual structure is often wronly ascribed. The real history of nuclear matrix manifestation is reported in this paper.
\end{abstract}

Key words: Nuclear matrix, nuclear residue, nuclear fractions, history of nuclear fractionation.

\section{INTRODUCTION}

The term "nuclear matrix" (NM)[1,2] implies a structure consisting mainly of nonhistone proteins which remain after extraction of chromatin, casually lipids and residual DNA from isolated cell nuclei. Morphologically the NM consists of extracted nucleoli, nuclear envelope (lamina) and intranuclear fibrogranular network.

As early as in 1947 it was accepted that cell nuclei contained only nucleoprotein composed of thymonucleic acid (DNA) and basic proteins - protamins or histones.

Only after 1940 a few data on the presence of non-basic proteins in cell nuclei or nucleoproteins appeared. Primarily non-histone proteins in bacterial and plant nucleoproteins were described by Belozersky[3, 4]. Then a protein with high sulfur content was isolated from thymus nuclei[5]. However the desiccation of the tissue and its rough treatment with organic solvents suggest that it was a highly denatured 
artifact. Later Stedman and Stedman[6] extracted isolated nuclei with mineral acid and termed the nonhistone protein remaining associated with nucleic acid as "chromosomin" supposing that it was a main constituent of the chromosomes.

Somewhat more reliable results belong to Mirsky and Pollister[7] and Mirsky and Ris[8] who isolated a non-histone tryptophane-containing protein from deoxyribonucleoprotein extracted from chromosomes and designated the "Residual from Chromosomes" remaining after this extraction.

Beginning from our studies on fractionation of cell nuclei we observed that nuclei isolated by non-aqueous methods as well as in acid medium usually used by previous workers contained denatured proteins and could not be resolved to fractions $[9,10]$. Only the nuclei obtained by the method of Dounce[11] using very dilute citric acid could be fractionated.

However, as these nuclei were contaminated with cytoplasm, we elaborated, using citrate buffer, a method which produced much more purified nuclei[9, 12, 13]. Employing this method we fractionated isolated nuclei from normal and malignant rat and human tissues.

With 1-2 M NaCl we extracted a "nucleoprotein" fraction consisting of DNA, histone and a tryptophane-containing protein. The proteinous residue could be then resolved to "acidic protein" extracted with dilute alkali and insoluble "residual protein" (Fig 1).

Properties, quantitative ratio and amino acid compositition of these fractions were studied. The acidic protein (AP) sedimented at $\mathrm{pH} 5.0$ 5.3 and contained about $2.5 \%$ tryptophane; the residual protein (RP) was free of tryptophane and constituted $5-10 \%$ of nuclear nitrogen. However, in nuclei isolated from malignant tumors it contained tryptophane and amounted to $50 \%$ of nuclear dry weight[9, 13-15]. Later we showed that RP of tumors could be resolved by extraction with hot alcohol to tryptophane-containing and tryptophane-free moieties[16].

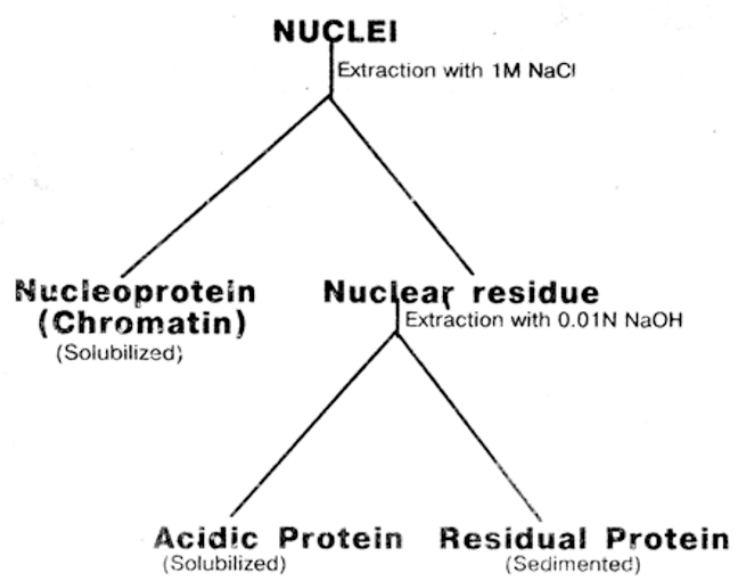

Fig 1. Scheme of nuclear fractionation [9]

Then, we developped the fractionation of cell nuclei by preliminary extraction of nuclear sap with $0.14 \mathrm{M} \mathrm{NaCl}$ and tentative treatment with DNase I. The fractions were, further, identified cytologically. Deep-freezed sections of various tissues were 
extracted in the cold with solutions mentioned above, then fixed in absolute alcohol and stained for nucleic acids and proteins with pyronine-methyl green, Feulgen reaction, bromphenol blue and combined Feulgen-bromphenol blue test.

0.14-0.40 M NaCl extracted nuclear sap contained non-chromatin protein and RNA. 1.5 M NaCl exhaustively solubilized chromatin. Extracted nucleoli and intranuclear structure resembling "residual chromosomes" of Mirsky and Ris[10] contained ribonucleoprotein and remnants of the nuclear envelope which were further identified as 'lamina' remained[17-19]. Extraction with $0.01 \mathrm{~N} \mathrm{NaOH}$ left only the latter[20-22].

Later, electron microscopy of nuclear fractions was studied in our laboratory and it was established that material remaining after extraction of nuclear sap and chromatin and DNase treatment consisted of extracted nucleoli and fibrogranular intranuclear network ("nucleonema") forming a so-called "nucleolo-chromosomal apparatus" attached to the remnants of the nuclear envelope[23-29].

Thus, in our studies (1948-1962) the initial data of non-chromatin nuclear proteins were obtained; their quantitative ratio, composition and accordance with cell organelles were established (Tab 1). Further, the cytological structures, representing nuclear skeleton (nuclear matrix) were verified by electron microscopy and confirmed in various laboratories[20, 30-33]. Our studies were cited and their priority acknow ledged by authoritative scientists[34, 35].

Tab 1. Composition of rat liver cell nuclei[26]

\begin{tabular}{|c|c|c|c|c|}
\hline Nuclear structure & Corresponding fraction & Solvent & $\begin{array}{l}\% \text { dry } \\
\text { nucleus }\end{array}$ & Composition of the fraction \\
\hline Nuclear sap & "Globulin" & $0.14 M \mathrm{NaCl}$ & 20 & RNA $2-8 \%$ \\
\hline DNP of chromatin & "Deoxynucleo protein" & $1-2 M \mathrm{NaCl}$ & 70 & $\begin{array}{l}\text { DNA } 33 \% \text {, Histone } 50 \% \\
\text { Nonhistone protein } 17 \%\end{array}$ \\
\hline $\begin{array}{l}\text { Nucleoli and residual } \\
\text { chromosomes }\end{array}$ & "Acidic protein" & $0.01 M \mathrm{NaOH}$ & $5-6$ & RNA $16-20 \%$ \\
\hline
\end{tabular}

On 21 April 1988, these findings were registered by State Committee of the USSR on inventions and discoveries as a discovery No. 348: "Property of nonhistone proteins of the cell nucleus to form non-chromatin structural carcass (nuclear matrix)" with the priority of August 27, 1948 and November 13, 1959. Reviews of these studies appeared in our articles[36, 37] and monographs[1, 38].

However, in the majority of later published papers, the history of the identification of the NM is often misrepresented[39]. Really, the exploration of the nuclear skeleton (or nuclear matrix) is a result of many studies to which Berezney and Coffey joined after 14 or even 26 years. Their studies developped and enriched this important branch of cell biology, but have nothing to do with its revelation. 


\section{REFERENCES}

[1] Zbarsky IB, Kuzmina SN Skeletnye structury kletochnogo yadra (Skeletal structures of the cell nucleus). Nauka: Moscow 1991.

[2] Berezney R, Coffey DS. Identification of a nuclear protein matrix. Biochim. Biophys Res Commun 1974; 60:1410-7.

[3] Belozersky AN. The protein and nucleic acid content of the bacterial cell. Mikrobioilogiya, 1940; 9:107-13.

[4] Belozersky AN, Uspenskaya MS. The nuclein complex of the germs and the proteins of the endosperm of cedar seeds (Pinus sibirica Rupr.) Biokhimiya 1942; 7:155-62.

[5] Mayer DT, Gulick A. The nature of the proteins of cell nuclei. J Biol Chem 1942; 146:433-40.

[6] Stedman E. Stedman E. Chromosomin, a protein constituent of chromosomes. Nature 1943; 152:267-9.

[7] Mirsky AE, Pollister AW. Chromosin, a deoxyribose nucleoprotein complex of the cell nucleus. J Gen Physiol 1946; 30:117-48.

[8] Mirsky AE, Ris H. The chemical composition of isolated chromosomes. J Gen Physiol 1947; 31:7-18.

[9] Zbarsky IB, Debov SS. On the proteins of cell nuclei. Doklady Acad nauk SSSR 1948; 62:795-8.

[10] Mirsky AE. Chemical properties of isolated chromosomes. Cold Spring Harbor Symposia on Quantitative Biology. Volume XII, Nucleic acids and nucleoproteins Cold Spring Harbor, New York, 1947:145-8.

[11] Dounce AL. Enzyme studies on isolated cell nuclei of rat liver. J Biol Chem 1943; 147:685-98.

[12] Zbarsky IB, Perevoshchikova KA. On some properties of cell nuclear proteins. Doklady Akad. nauk SSSR 1948; 60:77-80.

[13] Zbarsky IB. Chemistry of the cell nucleus. In: Zbarsky BI. ed. Uspekhy Biologicheskoy Khimii (Progress in Biological Chemistry) Academy of Medical Sciences of the USSR Publichers: Moscow 1950; vol.1:91-114.

[14] Zbarsky IB, Debov SS. Protein fractions of the cell nuclei. Biokhimiya 1951; 16:390-5.

[15] Debov SS. Quantitative content of protein fractions in cell nuclei of normal tissues and malignant tumors. Biokhimiya 1951; 16:314-20.

[16] Zbarsky IB, Debov SS. Studies on the residual nuclear protein of malignant tumors. Vopr Med Khimii 1955: 1:198-203.

[17] Zbarsky IB, Georgiev GP. Cytological Characteristics of protein and nucleoprotein fractions of cell nuclei. Biochim Biophys Acta 1959; 32:301-2.

[18] Georgiev GP. A histochemical study of nucleoprotein fractions of cell nuclei. Biokhimiya 1958; 23:700-6.

[19] Zbarsky IB, Georgiev GP. New data on protein fractions of rat liver cell nuclei and chemical composition of nuclear fractions. Biokhimiya 1959; 24:192-9.

[20] Soudek D, Beneš L. On protein constituents of the cell nucleus. Folia Biol (ČSSR) 1955; 1:261-7.

[21] Georgiev GP. Yermolaeva LP. Zbarsky IB. The quantitative relations between protein and nucleoprotein fractions in cell nuclei isolated from various tissues. Biokhimiya 1960; 25:318-22.

[22] Zbarsky IB. Composition and biosynthetic activity of nuclear structures. In: Proceedings of Vth International Congress on Biochemistry, Perga- mon Press, Oxford 1961; Symposium No. 2:1-11.

[23] Georgiev GP, Chentsov YS. On the structure of the cell nucleus. An experimental electron microscopical study of isolated nuclei. Doklady Acad nauk SSSR 1960; 132:199-202.

[24] Georgiev GP, Chentsov YS. On the structural organization of nucleolo- chromosomal ribonucleoproteins. Exper Cell Res 1962; 27:570-2.

[25] Zbarsky IB, Dmitrieva NP, Yermolaeve LP. On the structure of tumor cell nuclei. Exper Cell Res 1962; 27:573-6. 
[26] Zbarsky IB, Georgiev GP. Structure of the cell nucleus. Comparative correlation of cytochemistry and electron microscopy. Tsitologiya, 1962; 4:604-16.

[27] Zbarsky IB, Dmitrieva NP. Some features of cytochemistry of tumor cell nuclei. Acta Unio Intern Contra Cancrum 1962; 18:123-6.

[28] Zbarsky IB, Georgiev GP. Quelques aspects de la structure et du fonctionnement de l'appareil nucléaire de la cellule normale et cancéreuse. Colloque Franco-Sovétique, Moscou, 30 juillet $1962,35-45$.

[29] Zbarsky IB. La composition protéique et nucléique des structures nucléaires. Acta Histochem 1962; 7:89-93.

[30] Wang TY, Mayer DT, Thomas LE. A lipoprotein of rat liver nuclei. Exper Cell Res 1953; 4: 102-106.

[31] Smetana K, Steele WJ, Busch H. A nuclear ribonucleoprotein network. Exper Cell Res 1963; 31:198-202.

[32] Steele WJ, Busch H. Studies on acidic nuclear proteins of the Walker tumor and liver. Cancer Res 1963; 23:1153-63.

[33] Steele W J, Busch H. Studies on the composition of isolated nuclei of liver and Walker 256 carcinosarcoma. Exper Cell Res 1964; 33:68-72.

[34] Busch H. Histones and other nuclear proteins. Acad. Press: New York 1965:197-226.

[35] Shaper J, Pardoll D, Kaufmann S, Vogelstein B, Coffey DS. The relationship of the nuclear matrix to cellular structure and function. Adv Enzyme Regul 1979; 17:213-48.

[36] Zbarsky IB. Nuclear skeleton in some normal and tumor cells, Mol Biol Rep 1981; 7:139-48.

[37] Zbarsky IB. Nuclear matrix and its characteristics in normal and tumor cells In: Khrushchov NG. ed. Problems of Developmental Biology Mir: Moscow 1981:7-45.

[38] Organizatsiya kletochnogo yadra (Organization of the cell nucleus). Meditsina: Moscow 1988.

[39] Nickerson JA, Blencowe BJ, Penman S. The architectural organization of nuclear metabolism. Int Rev Cytol 1995; 162A:67-123.

Received March-31-1998. Revised May-20-1998. Accepted May-25-1998. 